\title{
Future of Mobile Commerce: An Exploratory Study on Factors affecting Mobile Users' Behaviour Intention
}

\author{
Arshan Bhullar*, Pushpinder Singh Gill \\ School of Management Studies \\ Punjabi University, Patiala, Punjab, India \\ E-mails: *arshanbhullar@gmail.com, ${ }^{\# p u s h p i n d e r g i l l 63 @ g m a i l . c o m ~}$ \\ ${ }^{*}$ Corresponding author
}

(Received February 11, 2018; Accepted August 16, 2018)

\begin{abstract}
Mobile commerce (M-commerce) being the subset of e-commerce, signifies a new field of business opportunity. The future of mobile commerce depends on how the mobile users' intend to adopt this new technology induced business model. With the success of e-commerce in India, there is a huge potential for m-commerce growth. As m-commerce technologies grow and mature, it is the users' experience and adoption of $\mathrm{m}$-commerce that will drive its growth. The users' acceptance of m-commerce depends upon various factors, which influence his/her behaviour towards $\mathrm{m}$ commerce. The current research is an effort to identify such antecedents that affects behavioural intention of mobile users towards m-commerce. A survey was conducted among 150 internet mobile users in Chandigarh city using structured self-administered questionnaire to identify such factors. The results show that perceived enjoyment and perceived usefulness are the most important factors followed by trust and perceived cost, which affects mobile users' behaviour intention to use m-commerce. Perceived ease of use and social influence was not found to have significant influence on mobile users' behaviour intention. The findings of this research show strong empirical base for all marketers and strategists who are looking to take full advantage of the strength of m-commerce.
\end{abstract}

Keywords- Behaviour intention, Mobile commerce, Mobile users, User adoption.

\section{Introduction}

Innovation is involved in every field, being it science or management. To survive and grow in the business world, the organizations need to continuously innovate and adapt to the changing business environment. In India, with the tremendous growth in internet penetration and advancement in wireless and mobile technologies, mobile phones are reshaping the modes how corporates do business and; also the ways how consumers interact with businesses. From business point of view, every business wants to grow and expand in a unique way but it is very difficult because of huge competitive market. Mobile commerce provides a unique way to expand the business by reaching new segment of consumers' i.e. the mobile users and providing better product and services. For adopting this new technology induced business model the business needs to consider those factors which drives mobile users to use m-commerce in the Indian scenario.

Mobile commerce (M-commerce) being the subset of e-commerce, signifies a new field of business opportunity. M-commerce supplements electronic commerce by allowing consumers to conduct online transactions via handheld device (Mahatanankoon, 2007). M-commerce is a way of doing business in a state of motion. Feng et al. (2006) defined m-commerce as a new and innovative business opportunity with unique characteristics like mobility and broader reachability. Shankar et al. (2010) described $\mathrm{m}$ - commerce to create a shift in the sales paradigm where instead of consumers arriving in the company's sales environment it is the seller who 
International Journal of Mathematical, Engineering and Management Sciences

Vol. 4, No. 1, 245-258, 2019

https://dx.doi.org/10.33889/IJMEMS.2019.4.1-021

influences the consumer's environment without any limitations of time and place through mobile devices. It is acknowledged that the web is taking part as a crucial role in our lifestyle. The web has become a vehicle for services instead of simply a static repository of knowledge. Mcommerce offers multiple advantages like Ubiquity, personalization, flexibility, and distribution, instant connectivity, immediacy; it is going to be next generation mode of business.

As compared to other developing nations, India is at the point of a digital revolution. With a tremendous increase in internet users and mobile users reaching over 400 million, India is entering into the phase of the Second Information Technology Revolution due to increased connectivity and Digital Revolution. As per IAMAI and IMRB report (2016), India has one of the fastest growing populations of internet users in the world-432 million as of December 2016 and growing rapidly. As per Internet world stats report, (2017), India has the second largest Internet population of 462 million in the world, after China who is having 738 million. The growth in the internet base in India has been exponential. The primary drivers of this exponential growth have been expansion of small town / rural India, increased affordability due to low cost data-enabled handsets, and the ever increasing awareness of, and need for, the Internet. According to IAMAI and IMRB, (2016) report the number of mobile internet users in India has reached 389 million as on December 2016 of which close to half of the mobile internet users are below 25 years of age and majority of them are students and young professionals. In term of usage activities on mobile internet; communication, social networking and entertainment are the top most usage activities in urban India and in rural India entertainment is mostly used by the people followed by social networking and communication.

Consumers today lead an increasingly fast-paced life and demand smaller, better, faster, and more reliable wireless technology to keep up with their lifestyles. M-Commerce is the solution to this demand because it makes traditional e-commerce tasks available to be performed wirelessly through a cell phone or PDA. Mobile is the latest happening thing not only in India but in the world. The advent of latest technologies in mobile handsets and sophisticated services by service providers has made Indian Mobile telecom market a buzz. The future of mobile commerce depends on how the mobile users' intend to adopt this new technology induced business model. With the success of e-commerce in India, there is a huge potential for m-commerce growth. As $\mathrm{m}$-commerce technologies grow and mature, it is the users' experience and adoption of $\mathrm{m}$ commerce that will drive its growth.

In India, there is lot of potential for businesses to grow in m-commerce, because it is still at infancy stage. So to study the adoption of m-commerce previous studies of other countries shows that they have used Technology Acceptance Model and its extended versions to identified factors which influence the adoption of m-commerce. But most of these studies had been carried out in other countries like Taiwan, China, USA. These studies were also based on traditional models like Technology Acceptance model (TAM), Theory of Planned Behaviour (TPB), Unified Theory of Acceptance and use of Technology (UTAUT), Diffusion of Innovation (DOI) model etc. There has been very few papers which focuses on identifying the factors which affects the behaviour intention of mobile users which will lead to adoption of mobile commerce in Indian context. So this study will provide a literature review on the acceptance of $\mathrm{m}$-commerce factors which impact the behaviour intention of mobile users. After that based on literature review a research model will be framed. The study integrates empirical modeling methods for testing the hypotheses and obtain the results which shows the significant factors which affect mobile users' behaviour intention towards m-commerce. 
International Journal of Mathematical, Engineering and Management Sciences

Vol. 4, No. 1, 245-258, 2019

https://dx.doi.org/10.33889/IJMEMS.2019.4.1-021

\section{Literature Review and Hypotheses Development 2.1 Mobile Commerce}

Mobile commerce is relatively new term, it is still at growing stage as compared to other information systems like e-commerce, internet banking, online shopping etc. New applications of mobile commerce are constantly developing with the advancement in $\mathrm{m}$-commerce technology. So over a period of time the definition of m-commerce has also evolved. Barnes (2002) defined $\mathrm{m}$-commerce as any transactions, either direct or indirect with a monetary value implemented via a wireless telecommunication network. Various researchers have defined m-commerce as an extension of e-commerce (Ngai and Gunasekaran, 2007; Wei et al., 2009). They concluded that $\mathrm{m}$-commerce is just an extension of electronic commerce and only difference is that the transactions are conducted over wireless internet technologies using mobile devices. On the other hand various authors have argued that m-commerce is much more than an extension of ecommerce. According to them M-commerce provides different business model than e-commerce as they interact differently with different users, they have different usage patterns and value chain (Feng et al., 2006). Tiwari and Basu (2007) stated m-commerce as m-business which not only include monetary transactions but also it has features which distinguish it from e-commerce like ubiquity, personalization, flexibility etc.

\subsection{Factors Affecting Behaviour Intention towards M-Commerce}

Previous studies on mobile commerce includes various models and frameworks to determine the adoption m-commerce technology in other countries. Various models are used like Technology Acceptance Model (TAM) (Davis, 1989), Theory of Panned Behaviour (TPB) (Ajzen, 1991), Diffusion of Innovation (DOI) (Roger, 1995), Theory of Reasoned Action (TRA). These models has been used by various authors to study the adoption of various Information technologies/ Information System. But the individual sturdiness and prediction vary for different kind of information technology. With respect to m-commerce, TAM is the most important model which has been used by various authors (Cho, 2008; Wei et al., 2009; Chong et al., 2012; Chong, 2013) in which two major variables i.e. perceived ease of use and perceived usefulness have been identified as crucial factors which predicts users' adoption of new technology. But many researchers have also suggested that TAM should be extended with additional variables to better predict users' behaviour intention towards m-commerce. So based on different characteristics of mobile commerce, the following variables has been identified from extensive literature review to extend the TAM by including additional variables which has an impact on behaviour intention of mobile users' towards m-commerce in India.

\subsubsection{Perceived Usefulness}

Perceived usefulness is defined as "the degree to which a person believes that using a particular system would enhance his or her job performance" (Davis, 1989). In a meta-analysis study by Jeyaraj et al. (2006) on information systems adoption it was found that perceived usefulness is most important and frequently studied factor. Perceived usefulness with respect to mobile commerce adoption has also been found as significant factors in various studies (Yang, 2005; Wei et al., 2009; Chong et al. 2010). Chong (2013) has identified that m-commerce is acceptable by mobile users only when they find it more useful than its alternatives like e-commerce. This conclusion has also been supported by Schierz et al. (2010), who also mentioned that one of the main reason of not using a new technology is that the users are not able to see the benefits of new technology. The usefulness of mobile services influences the usage pattern of m-commerce which include ubiquity, timeliness, customization etc. (Wong and Hiew, 2005). Therefore this study 
International Journal of Mathematical, Engineering and Management Sciences

Vol. 4, No. 1, 245-258, 2019

https://dx.doi.org/10.33889/IJMEMS.2019.4.1-021

consider perceived usefulness as important variable which impact behaviour intention of mobile users. So, following hypothesis is proposed:

H1: Perceived Usefulness has a positive and significant relationship with behaviour intention towards m-commerce.

\subsubsection{Perceived Ease of Use}

Perceived ease of use is one of the two crucial and important variable of TAM. Perceived ease of use is defined as "the degree to which a person believes that using a particular system would be free of effort" (Davis, 1989). An individual may find the technology useful, but it might be difficult to use. The technology of mobile devices is evolving consistently, so the users need to adapt to the latest technology with ease. Perceived ease of use variable has been studied and found to be an important determinant by many researchers in adoption of various latest technologies like the internet, mobile internet (Kim et al., 2007), m-commerce (Lin and Wang, 2005; Wang and Barnes, 2007). But in India, m-commerce is at initial stage of growth; it is important to study whether mobile users consider ease of use as important factor which influence his/her behaviour towards using m-commerce. Users are nowadays familiar with using mobile devices very efficiently, but new applications and features are introduced at a very rapid rate in the market. Chong et al. (2010) has identified an issue of tradeoff between ease of use and functionality of mobile devices which affects the designing of interface of mobile application. Some authors have also mentioned that the degree of complexity in using $\mathrm{m}$-commerce is highly affected by customer perception (Riquelme and Rios, 2010). So based on literature review, the following hypothesis is developed:

H2: Perceived Ease of Use has a positive and significant relationship with behaviour intention towards m-commerce.

\subsubsection{Perceived Enjoyment}

Perceived enjoyment is found to have very important role in adoption of various information systems (Thong et al., 2006). A mobile user will use internet on their mobile phone if he/she feels enjoyment, excitement or joy while using the internet and ultimately adopt the technology. The perceived enjoyment factor has been included in the extended versions of the TAM model because it was found to have direct and significant relationship with mobile commerce adoption (Kim et al., 2007). Teo (2001) found that perceived enjoyment is the main reason the users use internet on mobile phones for browsing and messaging. Therefore, the following hypothesis is proposed:

H3: Perceived Enjoyment has a positive and significant relationship with behaviour intention towards m-commerce.

\subsubsection{Trust}

Trust is an important factor which affects consumer behaviour. Over the years trust has been studied in various literatures. Pavlou (2003) studied trust in the context of e-commerce and stated that it is the willingness of consumers to become vulnerable to the online retailers. Wei et al. (2009) defined trust as the extent to which an individual believes that using mobile commerce is secure and will have no privacy threats. Trust in online business plays an important role because the buyer and seller never meets face to face (Chong et al., 2010). Gefen et al. (2003) also found that trust plays a vital role in influencing users' online purchasing intentions. M-commerce is a 
International Journal of Mathematical, Engineering and Management Sciences

Vol. 4, No. 1, 245-258, 2019

https://dx.doi.org/10.33889/IJMEMS.2019.4.1-021

new phenomenon and due to lack of regulation framework in India and lack of confidence among the users, trust becomes a vital factor which helps in building confidence among the users to adopt m-commerce. So, this study propose following hypothesis:

H4: Trust has a positive and significant relationship with behaviour intention towards mcommerce.

\subsubsection{Perceived Cost}

The perceived cost of using m-commerce is one of the vital factors which could affect the growth of $\mathrm{m}$-commerce. The cost of $\mathrm{m}$-commerce includes subscription cost, mobile device purchase price, maintenance cost. Wei et al. (2009) identified that cost can hinder in the successful development of m-commerce. Anil et al. (2003) also concluded that cost is a significant factor which influence the adoption of $\mathrm{m}$-commerce in Singapore. Previous studies have shown negative relationship of cost with different information technologies (Anil et al., 2003; Xin, 2004; Ong et al.; 2008). In India, the main concern is whether the mobile users consider cost as an important factor which impact his/her behaviour intention towards m-commerce or not. Most of the mobile users are young users who can be more sensitive to price than other categories of users. So it is vital to understand the impact of perceived cost on behaviour intention of mobile users towards $\mathrm{m}$-commerce. Therefore, this study hypothesis that:

H5: Perceived cost has a negative and significant relationship with behaviour intention towards m-commerce.

\subsubsection{Social Influence}

Social influence is defined as "the degree to which an individual perceives that important others believe he or she should use the new system" (Venkatesh et al., 2003). Ajzen (1991) defined social influence as to an extent an individuals' perception is affected by the belief of others who are important to him/her towards the use of an innovation. Many researchers have described social influence as subjective norms (Lu et al., 2003; Chong et al., 2010) and has identified it as significant factor in various models like Theory of Reasoned Action, Theory of Planned Behaviour, extended TAM and UTAUT. An individual behaviour of a mobile users is influenced by various external variables. Roger (1995) has divided social influence into two forms i.e. mass media and interpersonal variables. Mass media includes newspaper, social media, television, internet, magazines etc. and interpersonal variables includes, family and friends, peers, society etc. Fan et al. (2005) have found out that the social influence has more impact on m-commerce than perceived usefulness and perceived ease of use. So based on literature review, following hypothesis is developed:

H6: Social Influence has a positive and significant relationship with behaviour intention towards m-commerce.

\section{Research Framework}

The research model proposed for this study is shown in Figure 1. This study propose a research framework in which six independent variables has been identified through review of literature i.e. perceived usefulness, perceived ease of use, perceived enjoyment, trust, perceived cost and social influence. The impact of these independent variables will be studied on the behaviour intention of mobile users towards m-commerce. This study is an effort to enhance the usage intention of mobile users in India by integrating four additional variables that extend the TAM. The focus of 
International Journal of Mathematical, Engineering and Management Sciences

Vol. 4, No. 1, 245-258, 2019

https://dx.doi.org/10.33889/IJMEMS.2019.4.1-021

this research is to study the behaviour intention of mobile users towards m-commerce because in India it is still at infancy stage so instead of actual use, intention to use is chosen to study the adoption of m-commerce.

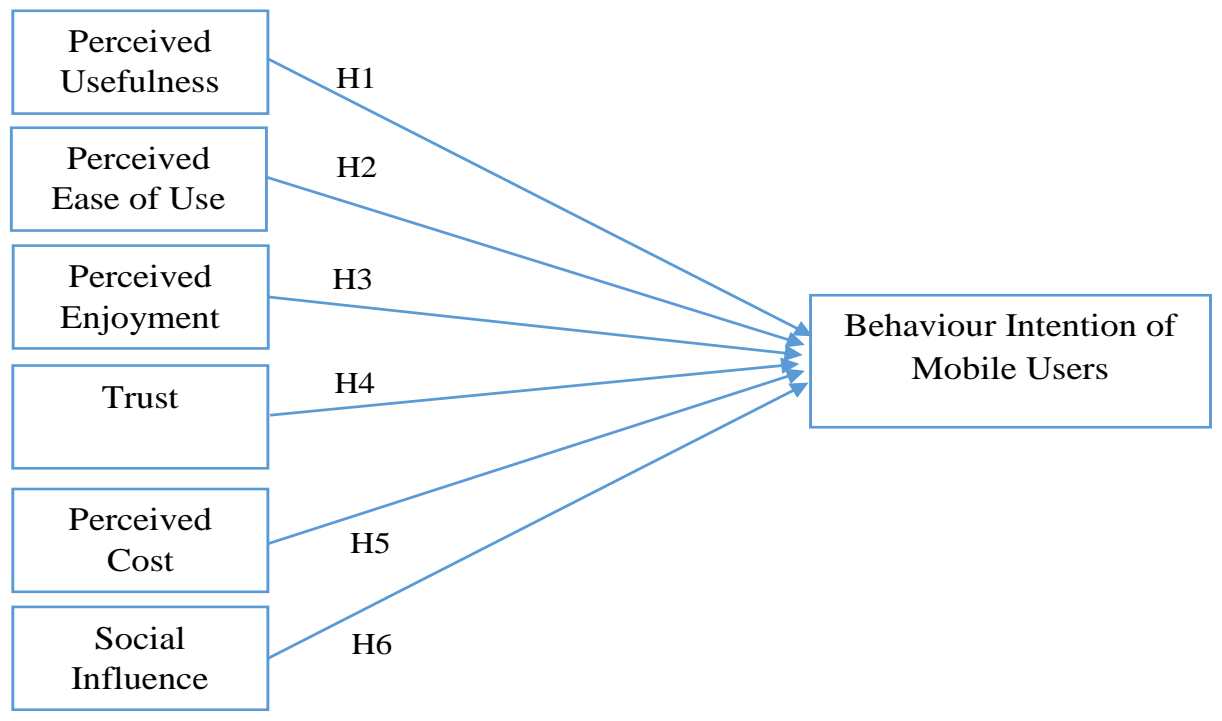

Figure 1. Research framework

\section{Research Methodology}

\subsection{Sampling and Data Collection}

Based on previous literature, a research model was developed, which included behavioural intention factors which have direct influence on mobile commerce adoption. Then the proposed model was pre tested with 20 mobile commerce users to ensure the content validity, which includes experts in the area of technology and university professors. Based on their feedbacks relevant changes were made and the final model was then empirically assessed to test the hypotheses using a survey questionnaire from 150 respondents using convenience sample approach. The data were collected from the internet mobile users of Chandigarh. The younger generation has been considered for data collection because they constitute as the largest segment for the use of latest technology as they adopts innovative technology quickly and also influence on older age segment of people to use the technology. All respondents had previous experience with mobile commerce and are currently using the internet on their mobile devices.

\subsection{Variable Measurement}

The proposed model examines the factors which affect the behaviour intention of mobile users towards mobile commerce. The independent variables of $\mathrm{m}$-commerce adoption has been derived from existing literature review. The questions were modified to fit the context of m-commerce. A total of 21 items for six constructs were used to identify the m-commerce adoption. These variables have been taken from previous studies of Davis (1989), Moon and Kim (2001), Luarn and Lin (2005), Wu and Wang (2005), Wei et al. (2009), and Chong (2013). To measure the mobile users' behaviour intention towards m-commerce four items were used which was derived from original TAM and other studies i.e. Luarn and Lin (2005), Shin (2007), Liao et al. (2007). 
International Journal of Mathematical, Engineering and Management Sciences

Vol. 4, No. 1, 245-258, 2019

https://dx.doi.org/10.33889/IJMEMS.2019.4.1-021

Five point Likert Scale ranging from 1 (Strongly Disagree) to 5 (Strongly Agree) is used to measure independent and dependent variables

\section{Data Analysis}

\subsection{Profile of Respondents}

The demographic profile of respondents is shown in Table 1. The demographic profile is categorized into three main categories, i.e. age, gender and education level. Among the 150 respondents majority of them were females (58.7\%) compared to males (41.3\%). As young mobile users of Chandigarh were considered for the study, most of the respondents lie in the age category of 18 to 22 years with $52 \%$, followed by $39.3 \%$ respondents of 23 to 27 years of age and $8.7 \%$ were between 28 to 32 years of age. The education qualification level of the respondents were categorized in four parts and it was found that the majority of them hold post-graduation degree (60.7\%). 36\% respondents were graduate. The other qualifications of respondents were identified as diploma and $\mathrm{PhD}$. which constitutes 3.3\%. Majority of the respondents were seen using m-commerce for 1 to 3 years i.e. $40.7 \%$ and only $18.7 \%$ of respondents were assessing mcommerce for more than 5 years which shows that m-commerce is still very new phenomenon and at infancy stage in India. In a day 34 per cent of the respondents were using m-commerce for 1 to 3 hours followed by 26 per cent respondents using it for 3-5 hours.

Table 1. Demographic profile of respondents

\begin{tabular}{|llcc|}
\hline \multicolumn{1}{|c}{ Variables } & Frequency & Percentage \\
\hline Age & $18-22$ & 78 & 52 \\
& $23-27$ & 59 & 39.3 \\
\hline Gender & $28-32$ & 13 & 8.7 \\
& Male & 62 & 41.3 \\
\hline Education Level & Female & 88 & 58.7 \\
& Graduation & 54 & 36 \\
& Post-Graduation & 91 & 60.7 \\
\hline Assessing M-commerce Frequency & Others & 5 & 3.3 \\
& Less than 1 year & 29 & 19.3 \\
& $1-3$ years & 61 & 40.7 \\
& $3-5$ years & 32 & 21.3 \\
& More than 5 years & 28 & 18.7 \\
\hline Using M-commerce in a day & Less than 1 hour & 36 & 24 \\
& $1-3$ hours & 52 & 34.7 \\
& $3-5$ hours & 39 & 26 \\
\hline
\end{tabular}

\subsection{Reliability and Validity Analysis}

Reliability of the questionnaire was tested using Cronbach's Alpha measurements and validity of the data was verified by applying Exploratory Factor Analysis. Table 2 shows the results from Reliability analysis done using Cronbach's Alpha. As Cronbach's Alpha values of all the variables are greater than 0.7 , all factors of the construct are reliable as recommended by Nunnally (1978). 
International Journal of Mathematical, Engineering and Management Sciences

Vol. 4, No. 1, 245-258, 2019

https://dx.doi.org/10.33889/IJMEMS.2019.4.1-021

Table 2. Reliability analysis

\begin{tabular}{|c|c|}
\hline Variables & Cronbach's Alpha \\
\hline Perceived Ease of Use & 0.778 \\
Perceived Usefulness & 0.737 \\
Perceived Enjoyment & 0.807 \\
Trust & 0.795 \\
Perceived Cost & 0.719 \\
Social Influence & 0.772 \\
Behaviour Intention & 0.730 \\
\hline
\end{tabular}

Construct validity is defined as "the degree to which a scale is measures what it intends to measure" (Garver and Mentzer, 1999). Exploratory Factor Analysis using Principal components extraction with varimax rotation was applied to test the construct validity of 25 items. Factor loading of 0.5 or more were considered as cutoff value for all the items and factor extraction was based on the Eigen value higher than 1 as suggested by Teo (2001) and Hair et al. (2006). The Kaiser-Meyer-Olkin (KMO) is measured at 0.681, which is above the threshold limit of 0.5 given by Field (2005). The Bartlett's test results of this study is significant with chi-square of 1025.471 (p-value $<0.01$ ). So both the results confirms that factor analysis is appropriate for data set.

Table 3 shows the result of factor analysis of all constructs with their factor loadings and Eigen value. As all the items have loading of 0.5 or more, the variables are considered to be unidimensional and factor distinct and all items are loaded on a single factor (Teo, 2001). The cumulative percentage of variance explained by six factors is 70.06 , which shows that 70 per cent of total variance shared by the 21 items can be explained by the six factor identified.

Table 3. Factor analysis

\begin{tabular}{|c|c|c|c|c|}
\hline Constructs & Scale Item & Factor Loadings & Eigen Values & $\begin{array}{l}\text { Percentage of } \\
\text { Variance }\end{array}$ \\
\hline Perceived Usefulness (PU) & $\begin{array}{l}\text { PU1 } \\
\text { PU2 } \\
\text { PU3 } \\
\text { PU4 }\end{array}$ & $\begin{array}{l}0.607 \\
0.612 \\
0.714 \\
0.781\end{array}$ & 2.271 & 13.817 \\
\hline Perceived Ease of Use (PEOU) & $\begin{array}{l}\text { PEOU1 } \\
\text { PEOU2 }\end{array}$ & $\begin{array}{l}0.560 \\
0.610\end{array}$ & 1.633 & 10.777 \\
\hline Perceived Enjoyment (PE) & $\begin{array}{l}\text { PE1 } \\
\text { PE2 } \\
\text { PE3 } \\
\text { PE4 } \\
\end{array}$ & $\begin{array}{l}0.753 \\
0.778 \\
0.789 \\
0.800 \\
\end{array}$ & 2.707 & 12.893 \\
\hline Trust (T) & $\begin{array}{l}\mathrm{T} 1 \\
\mathrm{~T} 2 \\
\mathrm{~T} 3 \\
\mathrm{~T} 4 \\
\end{array}$ & $\begin{array}{l}0.675 \\
0.784 \\
0.805 \\
0.813 \\
\end{array}$ & 2.589 & 12.330 \\
\hline Perceived Cost (PC) & $\begin{array}{l}\text { PC1 } \\
\text { PC2 } \\
\text { PC3 }\end{array}$ & $\begin{array}{l}0.679 \\
0.768 \\
0.828 \\
\end{array}$ & 2.072 & 10.867 \\
\hline Social Influence (SI) & $\begin{array}{l}\text { SI1 } \\
\text { SI2 } \\
\text { SI3 } \\
\text { SI4 } \\
\end{array}$ & $\begin{array}{l}0.515 \\
0.610 \\
0.658 \\
0.833 \\
\end{array}$ & 1.969 & 9.376 \\
\hline Behaviour Intention (BI) & $\begin{array}{l}\text { BI1 } \\
\text { BI2 } \\
\text { BI3 } \\
\text { BI4 } \\
\end{array}$ & $\begin{array}{l}0.666 \\
0.709 \\
0.754 \\
0.765 \\
\end{array}$ & 2.099 & 63.060 \\
\hline
\end{tabular}


International Journal of Mathematical, Engineering and Management Sciences

Vol. 4, No. 1, 245-258, 2019

https://dx.doi.org/10.33889/IJMEMS.2019.4.1-021

\subsection{Correlation Analysis}

In the first step of the statistical analysis, average score of multiple items for a factor was computed and used for measuring correlation and multiple regression. Pearson correlation analysis was conducted to examine the relationship between the variables (Wong and Hiew, 2005). As per Field (2013), the correlation coefficient value should not be more than 0.80 to avoid multicollinearity. Since the highest correlation coefficient is 0.603 , there is no problem of multicollinearity.

All the variables were found to be statistically significant at level $p<0.01$ (Table 4). All the six factors i.e. perceived Usefulness $(r=0.603, p<0.01)$, perceived ease of use $(r=0.510, p<0.01)$, trust $(\mathrm{r}=0.446, \mathrm{p}<0.01)$, social influence $(\mathrm{r}=0.360, \mathrm{p}<0.01)$, perceived enjoyment $(\mathrm{r}=0.573, \mathrm{p}<0.01)$ were found to be significantly and positively correlated to behaviour intention of mobile users' towards m-commerce. While perceived cost $(\mathrm{r}=-0.198, \mathrm{p}<0.01)$ was significantly correlated to behaviour intention negatively. The correlation between perceived enjoyment and behaviour intention was the strongest, followed by perceived usefulness and perceived ease of use.

Table 4. Pearson correlation coefficient analysis

\begin{tabular}{|c|c|c|c|c|c|c|c|}
\hline Constructs & PU & PEOU & T & PC & SI & PE \\
\hline PU & 1 & & & & \\
PEOU & $0.689 *$ & 1 & 1 & & \\
T & $0.312^{*}$ & $0.427^{*}$ & $-0.053^{*}$ & $0.024^{*}$ & 1 & \\
PC & $-0.045^{*}$ & $0.287^{*}$ & $0.186^{*}$ & $0.149 *$ & $0.042^{*}$ & 1 & \\
SI & $0.301^{*}$ & $0.335^{*}$ & $0.054^{*}$ & $-0.050^{*}$ & $0.212^{*}$ & \\
PE & $0.603^{*}$ & $0.510^{*}$ & $0.446^{*}$ & $-0.198^{*}$ & $0.360^{*}$ & $0.573^{*}$ \\
BI & & & & \\
\end{tabular}

Note: *Correlation significant at the level 0.01 (two-tailed)

\subsection{Multiple Regression Analysis}

Multiple Regression analysis is applied to study the relationship between a single dependent variable and several independent variables (Hair et al., 2006). The multiple regression analysis is used to test the hypotheses generated to study the behaviour intention of mobile users towards mcommerce. The results of the analysis is shown in Table 5.

To test the multicollinearity among the independent variables, Variance inflation factor (VIF) and Tolerance were calculated. The results showed that the VIF values of all the predictor variables i.e. perceived usefulness, perceived ease of use, perceived enjoyment, trust, perceived cost, and social influence were less than 10 and tolerance indicator were greater than 0.1 . So these results indicate that there exist no multicollinearity among the predictor variables.

The multiple regression analysis results shows that the $F$ statistics $(F=36.299)$ was significant at $\mathrm{p}<0.01$, thus confirms that the model is fit. This concludes that there is significant relationship between the adoption factors and behaviour intention of mobile users. The $\mathrm{R}^{2}$ i.e. coefficient of determination was 56.2 per cent. In other words, it can be derived that the identified adoption factors significantly account for $\mathbf{5 6 . 2}$ per cent in the behaviour intention of mobile users towards m-commerce. 
International Journal of Mathematical, Engineering and Management Sciences

Vol. 4, No. 1, 245-258, 2019

https://dx.doi.org/10.33889/IJMEMS.2019.4.1-021

Hypotheses were tested using multiple regression analysis and it was found that perceived usefulness, trust, perceived cost, perceived enjoyment have significant relationship $(p<0.01)$ with the mobile users' behaviour intention towards m-commerce. Perceived ease of use and social influence was not found to have significant effect on behaviour intention of mobile users.

Table 5. Multiple regression analysis

\begin{tabular}{|l|c|c|c|c|c|}
\hline \multicolumn{1}{|c|}{ Predictor Variable } & B & t-value & Sig & Tolerance & VIF \\
\hline Perceived Usefulness & 0.192 & 5.525 & 0.003 & 0.722 & 1.385 \\
Perceived Ease of Use & 0.077 & 1.004 & 0.317 & 0.699 & 1.431 \\
Trust & 0.159 & 4.387 & 0.008 & 0.931 & 1.079 \\
Perceived Cost & -0.204 & -2.932 & 0.004 & 0.858 & 1.165 \\
Perceived Enjoyment & 0.429 & 6.112 & 0.000 & 0.845 & 1.184 \\
Social Influence & 0.020 & 1.222 & 0.276 & 0.852 & 1.174 \\
\hline
\end{tabular}

Note: Overall Model F= 26.299; $\mathrm{p}<0.01 ; \mathrm{R}^{2}=0.562 ;$ Adjusted $\mathrm{R}^{2}=0.548$

\section{Discussion}

$\mathrm{M}$-commerce is at a very preliminary stage in India, so the need to understand the intention of mobile users' towards m-commerce is very important. The foremost objective of this study was to empirically examine the extended Technology Acceptance Model (TAM) given by various authors in context of mobile commerce and specifically in the Indian scenario because there has been very limited studies which consider Indian users' intention towards mobile commerce. Other than original TAM variables i.e. perceived ease of use and perceived usefulness; perceived cost, trust and perceived enjoyment were found to be significant. These results are consistent with prior researches done on m-commerce adoption (Luarn and Lin, 2005; Lin and Wang, 2005; Khalif and Ning Shen, 2008).

In line with various studies conducted on m-commerce adoption, perceived usefulness emerged as important factor to predict m-commerce adoption (Wei et al., 2009; Koenig-Lewis et al., 2010; Chong, 2013; Yadav et al., 2016). M-commerce provides considerable advantages like ubiquity, immediacy, personalization to the customers. So when the mobile users find $\mathrm{m}$-commerce more useful only then they will have positive behaviour intention towards m-commerce. Perceived Enjoyment was found to be the most significant factor which impact behaviour intention of mobile users to use m-commerce. This shows that because $\mathrm{m}$-commerce is still new in India, mobile users mainly perceive enjoyment by using m-commerce entertainment activities. These findings are in consistence with Thong et al. (2006) and Ha et al. (2007) who identified that mobile users mainly uses m-commerce for applications like games, videos and social networking. It is important to note that perceived enjoyment plays more vital role than perceived usefulness. This shows that mobile users are more attracted to entertainment than the usefulness of $\mathrm{m}$ commerce.

Trust was also found to be vital factor which derive behaviour intention of mobile users. The finding of this study is in support with the previous research works (Lin and Wang, 2005; Cho et al., 2007; Wei et al., 2009; Chong, 2013). As m-commerce is much newer than e-commerce, the issue of privacy and security is a major concern for consumers. The trust of mobile users is depended on the privacy and security of the transactions they do on mobile devices. Perceived cost was found to have significant but negative impact on behaviour intention of mobile users. Which implies that although many m-commerce applications are free but the consumers are still 
International Journal of Mathematical, Engineering and Management Sciences

Vol. 4, No. 1, 245-258, 2019

https://dx.doi.org/10.33889/IJMEMS.2019.4.1-021

influenced by the mobile purchasing cost and internet subscription cost (Lin and Wang, 2005; Wei et al., 2009; Chong, 2013). Most mobile users will use m-commerce if the cost of using mcommerce is reduced and reasonable.

Perceived ease of use was found to have insignificant relation with behaviour intention of mobile users towards m-commerce. This results contradict prior studies (Lin and Wang, 2005; Luarn and Lin, 2005) but it is in consistent with Cho et al. (2007), Wei et al. (2009), Chong (2013). This is mainly because now users are familiar with m-commerce devices and application, so they do not find $\mathrm{m}$-commerce difficult to use. Social influence was also found to be insignificant in predicting $\mathrm{m}$-commerce adoption. These results is in contradict with previous studies (Shin, 2007; Wei et al., 2009). This can be because m-commerce is much newer phenomenon and the users might not be influenced by the society or friend and family but by the usefulness of the technology.

\section{Managerial Implications of the Study}

This research studied the factors which affects the behaviour intention of mobile users towards mcommerce. Major implications of the study which will be helpful to all $\mathrm{m}$-commerce service providers, marketing agencies, telecommunication companies, m-retailers etc. for developing long term customer relationships are as follows.

Perceived enjoyment and perceived usefulness were the most significant factors which shows that mobile users' intention to use m-commerce will increase when they find it useful and enjoyable. So it is recommended that the service providers and strategists should focus on developing that content and application for mobile devices which are valuable and exciting for the users by considering unique characteristics of m-commerce such as ubiquity, personalization etc. Strong relationship of trust with behaviour intention of mobile users was found which implies that service providers should focus on the security and privacy protection of mobile users which ultimately develop their trust towards m-commerce. Furthermore, strategists should also consider the cost related to $\mathrm{m}$-commerce as to attract more mobile users to use $\mathrm{m}$-commerce by reducing cost and developing different promotion and pricing strategies.

Perceived ease of use and social influence were found to have insignificant relationship with behaviour intention of mobile users which implies that since majority of mobile users belong to young generation and have the experience of using internet on their computers so they found using internet on mobile devices very easy. The managers must take into account the demographic profile of its target customers while creating $\mathrm{m}$-commerce marketing campaigns. Because this study has shown that different age groups and education qualification level of the users might have different impact on behaviour intention towards m-commerce due to the level of awareness, knowledge and confidence level among them. The strategists should focus on developing usable applications and systems which are valuable and exciting to increase the adoption of mobile users' towards m-commerce.

The m-commerce service providers should also promote various usage and benefits of using mobile commerce by providing training and doing campaigns among rural people because future growth of $\mathrm{m}$-commerce is in the rural sector of India. The findings of this research show strong empirical base for all the marketers and strategists who are looking forward to take full advantage of the strength of the mobile commerce. 
International Journal of Mathematical, Engineering and Management Sciences

Vol. 4, No. 1, 245-258, 2019

https://dx.doi.org/10.33889/IJMEMS.2019.4.1-021

\section{Limitation and Future Studies}

There are a few limitations of this study. Firstly, India is a geographically dispersed country with the majority of people residing in rural areas, so the sample size taken for this study is not that significant as more people can be considered for generalizing results for the entire country. Secondly, the study was limited to Chandigarh only due to time constraint, so the future studies on vast scale can be conducted on different age groups of m-commerce users and also of different geographical areas. And lastly, this study identified only six factors which affects behaviour intention of mobile users towards m-commerce but there are other factors also which have an impact on mobile users' adoption. So there is scope of considering other factors like self-efficacy, compatibility, variety of service, personal innovativeness, perceived risk to study their impact on mobile commerce adoption in the future research model.

\section{Conflict of Interest}

The authors confirm that there is no conflict of interest to declare for this publication.

\section{Acknowledgement}

The authors acknowledge and express the gratitude to the reviewer's constructive comments and valuable suggestion towards the improvement of the paper.

\section{References}

Ajzen, I. (1991). The theory of planned behavior. Organizational Behavior and Human Decision Processes, 50(2), 179-211.

Anil, S., Ting, L. T., Moe, L. H., \& Jonathan, G. P. G. (2003). Overcoming barriers to the successful adoption of mobile commerce in Singapore. International Journal of Mobile Communications, 1(1-2), 194-231.

Barnes, S. J. (2002). The mobile commerce value chain: analysis and future developments. International Journal of Information Management, 22(2), 91-108.

Cho, D. Y., Kwon, H. J., \& Lee, H. Y. (2007, January). Analysis of trust in internet and mobile commerce adoption. In System Sciences, 2007. HICSS 2007. 40th Annual Hawaii International Conference on (pp. 50-50). IEEE.

Cho, Y. C. (2008). Assessing user attitudes toward mobile commerce in the US vs. Korea: Implications for M-commerce CRM. Journal of Business \& Economics Research, 6(2), 91-102.

Chong, A. Y. L. (2013). Mobile commerce usage activities: The roles of demographic and motivation variables. Technological Forecasting and Social Change, 80(7), 1350-1359.

Chong, A. Y. L., Chan, F. T., \& Ooi, K. B. (2012). Predicting consumer decisions to adopt mobile commerce: Cross country empirical examination between China and Malaysia. Decision Support Systems, 53(1), 34-43.

Chong, A. Y. L., Darmawan, N., Ooi, K. B., \& Lin, B. (2010). Adoption of 3G services among Malaysian consumers: an empirical analysis. International Journal of Mobile Communications, 8(2), 129-149.

Davis, F. D. (1989). Perceived usefulness, perceived ease of use, and user acceptance of information technology. MIS Quarterly, 319-340. 
International Journal of Mathematical, Engineering and Management Sciences

Vol. 4, No. 1, 245-258, 2019

https://dx.doi.org/10.33889/IJMEMS.2019.4.1-021

Fan, Y., Saliba, A., Kendall, E. A., \& Newmarch, J. (2005, July). Speech interface: an enhancer to the acceptance of m-commerce applications. In null (pp. 445-451). IEEE.

Feng, H., Hoegler, T., \& Stucky, W. (2006, June). Exploring the critical success factors for mobile commerce. In Mobile Business, 2006. ICMB'06. International Conference on (pp. 40-40). IEEE.

Field, A. (2013). Discovering statistics using IBM SPSS statistics. Sage publication.

Garver, M. S., \& Mentzer, J. T. (1999). Logistics research methods: employing structural equation modeling to test for construct validity. Journal of Business Logistics, 20(1), 33.

Gefen, D., Karahanna, E., \& Straub, D. W. (2003). Trust and TAM in online shopping: An integrated model. MIS Quarterly, 27(1), 51-90.

Ha, I., Yoon, Y., \& Choi, M. (2007). Determinants of adoption of mobile games under mobile broadband wireless access environment. Information \& Management, 44(3), 276-286.

Hair, J. F., Black, W. C., Babin, B. J., Anderson, R. E., \& Tatham, R. L. (2006). Multivariate data analysis (Vol. 6).

IAMAI and IMRB Report (2016), "Internet in India 2016", jointly published by the Internet and Mobile Association of India (IAMAI) and IMRB International, http://www.iamai.in/res earch/reports_details/4860 [Accessed $24^{\text {th }}$ January 2018].

Internet World Stats Report, (2017), Available From: <http://www.internetworldstats.com/top20 .htm> [Accessed 26 ${ }^{\text {th }}$ October 2017].

Jeyaraj, A., Rottman, J. W., \& Lacity, M. C. (2006). A review of the predictors, linkages, and biases in IT innovation adoption research. Journal of Information Technology, 21(1), 1-23.

Khalifa, M., \& Ning Shen, K. (2008). Explaining the adoption of transactional B2C mobile commerce. Journal of Enterprise Information Management, 21(2), 110-124.

Kim, H. W., Chan, H. C., \& Gupta, S. (2007). Value-based adoption of mobile internet: an empirical investigation. Decision Support Systems, 43(1), 111-126.

Koenig-Lewis, N., Palmer, A., \& Moll, A. (2010). Predicting young consumers' take up of mobile banking services. International Journal of Bank Marketing, 28(5), 410-432.

Liao, C. H., Tsou, C. W., \& Huang, M. F. (2007). Factors influencing the usage of 3G mobile services in Taiwan. Online Information Review, 31(6), 759-774.

Lin, H. H., \& Wang, Y. S. (2005, July). Predicting consumer intention to use mobile commerce in Taiwan. In Mobile Business, 2005. ICMB 2005. International Conference on (pp. 406-412). IEEE.

Lu, J., Yu, C. S., Liu, C., \& Yao, J. E. (2003). Technology acceptance model for wireless Internet. Internet Research, 13(3), 206-222.

Luarn, P., \& Lin, H. H. (2005). Toward an understanding of the behavioral intention to use mobile banking. Computers in Human Behavior, 21(6), 873-891.

Mahatanankoon, P. (2007). The effects of personality traits and optimum stimulation level on textmessaging activities and m-commerce intention. International Journal of Electronic Commerce, 12(1), 7-30.

Moon, J. W., \& Kim, Y. G. (2001). Extending the TAM for a World-Wide-Web context. Information \& Management, 38(4), 217-230.

Ngai, E. W., \& Gunasekaran, A. (2007). A review for mobile commerce research and applications. Decision Support Systems, 43(1), 3-15.

Nunnally, J. C., \& Bernstein, I. H. (1978). Psychometric Theory McGraw-Hill New York Google Scholar. 
International Journal of Mathematical, Engineering and Management Sciences

Vol. 4, No. 1, 245-258, 2019

https://dx.doi.org/10.33889/IJMEMS.2019.4.1-021

Ong, J. W., Poong, Y. S., \& Ng, T. H. (2008). 3G services adoption among university students: Diffusion of innovation theory. Communications of the IBIMA, 3(16), 114-121.

Pavlou, P. A. (2003). Consumer acceptance of electronic commerce: Integrating trust and risk with the technology acceptance model. International Journal of Electronic Commerce, 7(3), 101-134.

Riquelme, H. E., \& Rios, R. E. (2010). The moderating effect of gender in the adoption of mobile banking. International Journal of Bank Marketing, 28(5), 328-341.

Rogers, E. M. (1995). Diffusion of Innovations. The Free Press: New York, NY, USA.

Schierz, P. G., Schilke, O., \& Wirtz, B. W. (2010). Understanding consumer acceptance of mobile payment services: An empirical analysis. Electronic Commerce Research and Applications, 9(3), 209-216.

Shankar, V., Venkatesh, A., Hofacker, C., \& Naik, P. (2010). Mobile marketing in the retailing environment: current insights and future research avenues. Journal of Interactive Marketing, 24(2), 111-120.

Shin, D. H. (2007). User acceptance of mobile Internet: Implication for convergence technologies. Interacting with Computers, 19(4), 472-483.

Teo, T. S. (2001). Demographic and motivation variables associated with Internet usage activities. Internet Research, 11(2), 125-137.

Thong, J. Y., Hong, S. J., \& Tam, K. Y. (2006). The effects of post-adoption beliefs on the expectationconfirmation model for information technology continuance. International Journal of HumanComputer Studies, 64(9), 799-810.

Tiwari, R., \& Buse, S. (2007). The mobile commerce prospects: a strategic analysis of opportunities in the banking sector. Hamburg University Press. ISBN 978-3-937816-31-9.

Venkatesh, V., Morris, M. G., Davis, G. B., \& Davis, F. D. (2003). User acceptance of information technology: Toward a unified view. MIS Quarterly, 425-478.

Wang, S., \& Barnes, S. (2007, July). Exploring the acceptance of mobile auctions in China. In Management of Mobile Business, 2007. ICMB 2007. International Conference on the (pp. 27-27). IEEE.

Wei, T. T., Marthandan, G., Yee-Loong Chong, A., Ooi, K. B., \& Arumugam, S. (2009). What drives Malaysian m-commerce adoption? An empirical analysis. Industrial Management \& Data Systems, 109(3), 370-388.

Wong, C. C., \& Hiew, P. L. (2005, July). Factors influencing the adoption of mobile entertainment: Empirical evidence from a Malaysian survey. In Mobile Business, 2005. ICMB 2005. International Conference on (pp. 682-685). IEEE.

Wu, J. H., \& Wang, S. C. (2005). What drives mobile commerce? : an empirical evaluation of the revised technology acceptance model. Information \& Management, 42(5), 719-729.

Xin, X. (2004). A model of $3 \mathrm{G}$ adoption. AMCIS 2004 Proceedings, 329.

Yadav, R., Sharma, S. K., \& Tarhini, A. (2016). A multi-analytical approach to understand and predict the mobile commerce adoption. Journal of Enterprise Information Management, 29(2), 222-237.

Yang, K. C. (2005). Exploring factors affecting the adoption of mobile commerce in Singapore. Telematics and Informatics, 22(3), 257-277. 